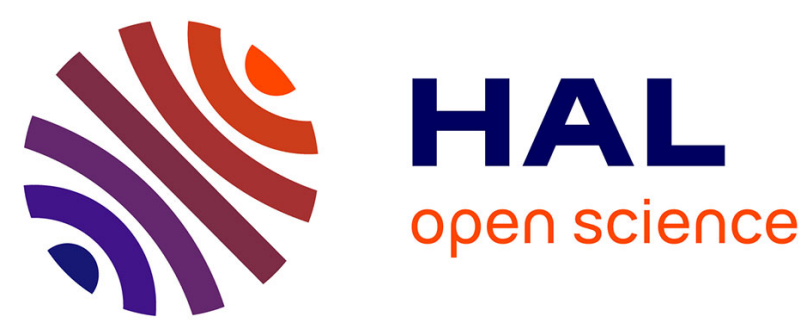

\title{
THYROXINE AND TRIIODOTHYRONINE DEGRADATION IN LINES OF PIGS SELECTED FOR RATE OF GAIN AND THICKNESS OF BACKFAT
}

\author{
N. Standal, B. Tveit, A. Eggum, P. M. Dahl
}

\section{> To cite this version:}

N. Standal, B. Tveit, A. Eggum, P. M. Dahl. THYROXINE AND TRIIODOTHYRONINE DEGRADATION IN LINES OF PIGS SELECTED FOR RATE OF GAIN AND THICKNESS OF BACKFAT. Annales de génétique et de sélection animale, 1980, 12 (1), pp.126-126. hal-00893175

\section{HAL Id: hal-00893175 \\ https://hal.science/hal-00893175}

Submitted on 1 Jan 1980

HAL is a multi-disciplinary open access archive for the deposit and dissemination of scientific research documents, whether they are published or not. The documents may come from teaching and research institutions in France or abroad, or from public or private research centers.
L'archive ouverte pluridisciplinaire HAL, est destinée au dépôt et à la diffusion de documents scientifiques de niveau recherche, publiés ou non, émanant des établissements d'enseignement et de recherche français ou étrangers, des laboratoires publics ou privés. 
THYROXINE AND TRIIODOTHYRONINE DEGRADATION

IN LINES OF PIGS SEI,ECTED FOR RATE, OF GAIN AND THICKNESS OF BACKFAT

N. STANDAL, B. TVEIT, A. EGGUM, P. M. DAHL

Dept of Animal Genetics and Breeding, Agricultural University of Norway, As - N.L.H.

A selection esperiment in two directions has produced lines for pigs that differ considerably in fat/lean ratio and also in growth rate. It has been hypothezised that the selection for thin backfat may have altered the metabolic rate of the pigs.

In order to investigate this hypothesis, thyroid activity parameters were estimated in I2 pigs, from each of the two selection lines, at a live weight of about $40 \mathrm{~kg}$.

There was a slight difference between the two selection lines in triiodothytonine degradation constant, and $T_{3}$ serum level. For the other tested parameters, $T_{3}$ and $T_{4}$ distribution space, $T_{3}$ and $T_{4}$ degradation $/$ day, $T_{4}$ degradation constant and $T_{4}$ serum level there was no significant difference between the two selection lines. The line difference in percent dissected fat in the half carcass amounted to about $\mathrm{I} 3$ percentage units, and was very highly significant.

It was concluded that the thyroid activity measurements did not give clear evidence of a difference in metabolic rate between the two selection line.

DIFFICULTIES WITH THE GENETIC IMPROVEMENT OF FEED EFFICIENCY IN BROILER I,INES USING GROUP CAGE INFORMATION

\section{K. FLOCK, F. MARAHRENS}

\section{Lohmann Tierzucht GmbH, Cuxhaven, W. Germany}

Progeny or sib testing in group cages may become a useful tool for broiler breeders who wish to improve feed efficiency directly. Protlem areas today are : $(I)$ the investment and operating cost for measuring family feed consumption on a large enough scale to have an impact on the commercial broiler; (2) mortality, which tends to be higher than under floor management and contributes to the inaccuracies of measuring feed intake; (3) leg problems, which limit the possible selection intensity for growth rate and feed efficiency; and (4) the expected decrease in rate of progress for growth rate.

SELECTION ON FEED EFFICIENCY IN LAY HENS : DIRECT AND CORRELATED RESPONSE

\section{G. HEIL*, F. PIRCHNER}

Lehrstuhl für Tierzucht, Weiheustephan, Bayern

* Institut $f$. Kleintierzucht der Bundesforschungsanstalt $f$. Landwirtschaft, Braunschweig-Volkenreede D-3Ior Celle

Two Leghorn-lines were selected for feed efficiency over three generations with a reciprocal recurrent selection program. Selection response was estimated by using a repeated mating scheme. Furthermore a comparison could be made between generation 3 of this experiment and lines of the same origin selected for egg production. The following results could be observed. Body weight feed consumption and egg weight decreased due to selection for feed efficiency. A slight increase in the egg production rate could be seen. Feed efficiency changed from 2.46 in generation o to 2.22 in generation 3 in terms of $\mathrm{kg}$ feed used to produce one $\mathrm{kg}$ eggmass. The lines selected for egg production laid more and heavier eggs, had a higher body weight and a greater feed intake than the lines selected directly for feed efficiency. For the production of one $\mathrm{kg}$ eggmass they used $2.34 \mathrm{~kg}$ feed. 